\title{
CHANGING MONGOLIA IN A NEW ENVIRONMENT
}

\section{Dugersuren}

\section{Background}

Mongolia is a small developing country populated by a little over two million people scattered unevenly over 1.5 million square kilometers. Geopolitically, it is a nuclear-weapons-free state jammed between two nuclear giants whose com-bined population makes up approximately one quarter of mankind.

Mongols belong to the same stock as Chingis Khan and his descendants who created in the thirteenth century an empire comprising virtually the whole of continental Asia and a substantial part of Europe. They sowed death and destruction and have been called barbarians, world conquerors, earth shakers, devil's horsemen, and the like. Their contributions to civilization are questioned widely, and they have received less appreciation and more scorn.

By the end of the seventeenth century Mongolia fell under the Manchu empire of China, mainly due to the internecine struggle which precipitated the disintegration of the nation. It became a terra incognita to much of the world until very recently.

However, due to its unique geopolitical situation. Mongolia became destined to get deeply involved in the whirlwind of the liberation movement of the twentieth century In 1911 the two hundred-year old Manchu rule was overthrown and an independent monarchy was proclaimed. The gloomiest chapter in Mongolia's Hilton was terminated but the militarist rulers of China managed, with the connivance of Tsarist Russia, to reduce that hard-won independence to autonomy by imposing in 1915, lhe so-called tripartite (China, Russia. Mongolia) Treaty of Kiahta They then proceeded in 1919 to further subjugate Mongolia by brute force while the new Russia had its hands tied by civil war and foreign intervention

In the meantime, the liberation movement of the Mongolian people developed into a national democratic revolution and with the assistance of Soviet Russia, Mongolia's independence was regained and a constitutional monarchy was established in July 1921. Democratic changes in the political, social and economic spheres were started. Unfortunately, due to its disadvantageous geopolitical location, Mongolia found itself encased in the socialist ideology from 
the late 1920s on to become the first Asian country to embrace communism The legacy of the long ordeal that had brought the nation to the brink of extinction, lack of wider congenial international communications and the resultant inferiority complex and irritation had also their part to play. There were gross blunders and distortions in the new socioeconomic experiment in the early years, and the 1930s witnessed deplorable cases of national tragedy. Nonetheless, on balance it must be said that the path traversed up to 1990 had brought Mongolia a national renascence, strengthened its sovereignty and helped it join the mainstream of modern history and human progress.

Mongolia has lately attracted much attention from the world community. An impressive peaceful demonstration in Ulaanbaatar's main square in January 1990 heralded the advent of a new period in Mongolia's national life. The events in its wake gave a powerful impetus to the faltering changes that had begun to take place since 1987 and developed the whole process into a third revolution in Mongolia's twentieth-century history. This revolution has led to the following changes:

- The souci-political democratization and the advancement of human rights and fundamental freedoms;

- The transition to a market economy with a guarantee of equality for different forms of property;

- The pursuance of an open foreign policy and multidimensional international activity;

- The revival of progressive national traditions in all spheres of life and the creation of a rational blend of values of national cultural heritage and modern civilization; and

- The recognition of the imperative of an enlightened and rational environmental policy to ensure sustained development.

These changes were ratified by the 1992 Constitution which provides the basic guarantees for a democratic and humane civil society. They are clearly consonant with the trends that prevail in the world today. At the same time, they revive and enhance the democratic values of the 1911 national liberation movement and the 1921 democratic revolution. Finally, they have helped Mongolia do away with the ideologically induced international isolation and have raised hopes for a better future. 


\section{Opportunities and Challenges}

The old social structure has been basically dismantled and the democratic process is steadily gaining ground. In 1992 the election to the national legislature, the Great Hural, took place on the basis of multi-party participation. In 1993 the president of the country was elected for the first time through universal suffrage, and the candidate nominated by the coalition of new democratic parties won the contest. This represents an important asset in enhancing the democratic process and political stability.

The minds of the people have been emancipated in search for a genuine and proper national identity. The nationalist spirit has been animated though its expression is often tumultuous and at times not free from mistakes and excesses. Legal frameworks for reforms and democratic changes are being laid down on the basis of the new Constitution.

Livestock, representing the mainstay of the national economy, has been privatized. The bulk of the industrial enterprises has been transferred to shareholders, and private ownership of land has been constitutionally guaranteed for Mongolian nationals. Although the inertia of a sponger mentality still persists, a sense of enterprise and the notion of a self-supporting economy seem to be gradually sprouting their first tender shoots.

Mongolia's commitment to and efforts toward democracy, economic reform and openness have met with impressive support from the international community. The technical, financial and material support provided by developed donor countries, the leading world economic and financial organizations, and the United Nations system has become an indispensable factor for the country's development along its chosen road.

Here I must add that the consecutive joint meetings of donor countries and international institutions of developmental cooperation have once again shown that continued external support is essential for making the democratic changes in Mongolia irreversible and lasting.

Yet, like all other countries undergoing major structural readjustments, Mongolia is going through a difficult and critical period fraught with a host of challenges and pitfalls. It experiences a deep economic crisis. Difficulties usually concomitant with the transitional process were drastically exacerbated by the unraveling of the previous foreign economic relations structure, and by the sudden disruption of financial and economic assistance from the former Soviet Union, which had supplied the lion's share of resources needed for the country's capital investment as well as for purchase of machinery, fuel and essential con- 
sumer goods The country's productive capacity continues to plummet, and the declining standard of living is causing widespread poverty. Unemployment, virtually non-existent before, is sharply increasing. Productive entrepreneurship is lagging whereas unproductive profiteering thrives, often at the expense of public assets. Lax discipline, poor management, distortions of privatization, and corrupt practices among bureaucrats further sap the economy. Widely held misconceptions and abuses of individual freedom weaken civic discipline, undermine law and order, and cause an increase in crime.

The relatively well-developed systems of education and medical care are in danger of being seriously crippled. Vulnerable groups, especially women, children, the aged and the handicapped, are most painfully affected.

In the face of such a dismal situation the nation is determined to implement economic reforms, to build, within a reasonable period, a self-supporting market-oriented economy, and to strengthen the country's viability and resilience under the these new conditions. In this effort, Mongolia attaches great importance to the effective use of its own available resources and foreign assistance and to deriving increasing benefit from the knowledge and experience of other Asian countries which have recently gained spectacular achievements in their socioeconomic development.

\section{Foreign Policy Priorities}

We are keenly aware of the indispensable role that a realistic and pragmatic foreign policy and open international behavior are destined to play in Mongolia's search for its proper place in the new world order.

In my view, the salient features of the international situation are as follows:

- The rejection of imperial policies and the firm vindication of the ideas and principles of non-alignment, reconciliation and equitable partnership;

- The deliverance of the United Nations from cold-war confrontation, giving it a second life as the main world organ playing the central role in safeguarding universal peace and the promotion of collective security and cooperative progress;

- The universal recognition of the imperative of the protection and rehabilitation of the natural environment as the vital means of ensuring sustained development and the survival of mankind; and

- The upholding of human rights and fundamental freedoms as an uncontested universal value. 
Recent events in the Middle East, South Africa and Cambodia clearly attest to the prevalence of common sense and pragmatism, and of the spirit of political reconciliation and cooperation among nations. At the same time, these events, reflecting the intrinsic complexity of the whole transitional process, are destined to experience formidable difficulties and even temporary setbacks. The ratification of the Maastricht Treaty and the signing of the Marrakech Trade Agreement show in their own way the magnitude of the trends underway.

On the other hand, there are many problems which cause serious concern in the international community and tend to aggravate and destabilize the global situation:

- The threat of the proliferation of nuclear and other weapons of mass destruction and their means of delivery still looms large while the spread of high-tech conventional armaments tends to gain momentum;

- Global economic relations are beset by unhealthy competition, protectionism, and a widening North-South gap whereas interdependence with all its boons and banes is growing apace;

- While the old political-military rivalry slowly wanes, new ideological and strategic contradictions tend to assert themselves, much to the alarm of the international community. A superpower is bent on asserting world leadership while a quickly rising giant vows to fight this form of hegemonies. Whereas the former considers socialism a curse, the latter is determined to vindicate the role of that system in human progress. There is a tendency toward North-South polarization on the approach to human rights issues.

Concern has begun to be expressed that a new cold-war type of confrontation might be brewing in relations between east and West and North and South. Such a phenomenon stems mainly from the differences in approaches to the thorough restructuring of global economic relations and to human rights issues. A universally agreed upon fair strategy for global growth is vitally needed.

In this connection, endorse the view that without eliminating poverty and external debt, no international order will be genuine and durable. Questions of free trade and fair prices for the products of the developing world should be speedily settled. The "iron curtain" erected by the developed countries in the fields of economic, scientific and technological exchanges must finally be brought down for the benefit of all. 
I believe that a moral revolution should take place in the approaches to world affairs. A sense of empathy, solidarity and humanity and the cognition of a common destiny must ultimately replace the indifference, selfishness and injustice that are prevalent especially in economic and technological relations.

I would like to commend the debate on the reactivation of the North-South dialogue to strengthen international cooperation for development which started at the July 1993 meeting of the chairmen of the Non-Aligned Movement and G77 in Tokyo and was continued at the 48th session of the UN General Assembly.

I wish to turn now to a large and complicated issue. National, racial, ethnic and religious conflicts represent the most serious threat to international peace and stability. One may say with a certain justification that the world has bogged down in the quagmire of such conflicts and intervention.

Civil wars in a number of African countries and especially the "ethnic cleansing" holocaust in the former Yugoslavia greatly disturb the situation in the respective regions and beyond. I may add here that Bosnia seems to have become a testing ground for the U.S. -sponsored and NATO-delivered Partnership for Peace program. In Russia, the political crisis which has caused bloodshed and continued economic turmoil, unless checked speedily, will have farreaching malignant consequences for world stability. Among other things, it imposes an extra burden on the world economy which grapples with problems of recession and a sluggish recovery.

If the situation in that huge Eurasian land mass further deteriorates, it will have serious repercussions in the Asia-Pacific region whose existing stability and prospect of continued steady economic growth are of vital importance to the world. In the first place, we have in mind Northeast Asia where there is a vulnerable spot, the Korean peninsula. Such vital issues as the reunification of Korea and the denuclearization of the peninsula may receive a setback and every effort should be made not to squander the favorable international momentum which has been created lately.

Given such complex and volatile global environment, Mongolia is trying to formulate the concepts and approaches of an open foreign policy which would best serve its interest to ensure national security by political means and help con-tribute within its capacity to the shared values of international peace, development and democracy.

Mongolia has discarded the lopsided international stance of the cold-war period and has opted for a policy of non-alignment which stems from its status of a developing country. It has broadened its diplomatic outlook and the scope of its international activities, and it has adhered to the principle of flexible priori- 
ties in foreign policy implementation with due consideration of the changes occurring in the international environment.

It should always be kept in mind that while the concept of Mongolia's foreign policy is determined by its national interest, the objectives, directions and methods of international behavior are basically influenced by Mongolia's geopolitical situation. Hence, friendly relations and mutually advantageous cooperation in various fields with our two immediate neighbors represent the first priority of Mongolia's international activities. Important steps at the highest laves have been taken to shape anew these relations on the basis of novel approaches. Their aim is to strengthen the foundations of genuine equality and mutual benefits in the spirit of prevailing trends in international politics.

Mongolia's unique geographical location enjoins it to create 'vested' interests of other major powers in the country. In other words, Mongolia tries to establish in its immediate surrounding a power equation most attuned to its national interest. Thus the development of active relations with the United States and Japan on the basis of mutual benefit and respect for legitimate interests constitutes a foreign policy objective of a very high priority for us.

While pursuing such goals, the following consideration should be strictly borne in mind. First, political considerations should clearly be present when choosing partners in projects vital to national security. Second, involvement in disputes, especially those in light of great power politics, should be avoided unless they immediately affect the country's national interest. Third, excessive dependence on any single power should be eschewed.

At the same time, it should be made amply clear that friendly attitudes toward all nations and respect for their legitimate interests and rights represent one of the fundamentals of Mongolia's international behavior. Mongolia is convinced that such a stance greatly benefits its international position and security.

Within this wider context special importance is attached to enhancing cooperative relations with Asian countries, including India, Korea, Singapore, and Thailand. Also, cooperation with countries like Germany, Great Britain, France, Canada, and Australia occupies a significant place. Due attention is also given to the continuation of traditional relations with the countries of the Commonwealth of Independent States, especially those in Central Asia, on a new basis. I would like to say that political, economic and cultural intercourse with ethnic Mongols in contiguous areas and beyond could become a very important part of Mongolia's international cooperation. At the same time Mongolia has to be alert and enterprising in order to avoid marginalization which is a widespread curse for weaker developing countries. 
One of Mongolia's highest priorities is the identification of its due place in the Asia Pacific community and in the rational participation in the political, security and economic arrangements of this vast region. Mongolia is keenly interested in making its contribution to the Asia-Pacific Multilateral Security Dialogue Mechanism and the ASEAN Regional Forum. It is keenly interested in promoting cooperation among countries of Northeast Asia, seeing it as a key component of the broader Asia-Pacific economic structure and a pivot of the world power equation with the increasing interaction of China, Japan, Russia and the United States. Mongolia is anxious to contribute to regional development programs such as the Tumen River Basin project.

Active participation in the work of the United Nations and its various organizations remains one of Mongolia's most important objectives. We will continue to contribute, however modest, to the peaceful and equitable solution of pressing problems on the basis of universal values and the principles of the Charter. As I mentioned earlier, the United Nations is destined to become the single most authoritative body to govern the world order in all fields of human activity. As a small developing country Mongolia is deeply interested in benefiting from the Unified Nations' increasing efforts to protect and guarantee the independence and integrity of nations, especially smaller and weaker ones, in times of crisis. It is of great value to Mongolia to share in the wealth of knowledge and experience accumulated by UN institutions in diverse fields of developmental activity.

Since it gained its independence, Mongolia has always striven to build up friendly relations with all developing countries. Due to geographical, financial and other constraints, bilateral intercourse with these nations is limited, and practical cooperation is maintained and strengthened mainly through multilateral channels in the framework of the United Nations, the Non-Aligned Movement, G-77 and various non-governmental organizations.

In conclusion, I would like to emphasize the need to improve the process of foreign policy making and implementation so as to foster a positive, mature and imaginative diplomacy. It is vital to create conditions for those who implement foreign policy to fully equip themselves with clear perceptions, innovative thinking and active attitudes. 